\title{
An Agonistic Theory of Democratic Parliamentarism. The Case of the Walloon Parliament
}

\author{
Archibald Gustin \\ Institut de la Décision Publique, Université de Liège, Liège, Belgique \\ Email: archibald.gustin@uliege.be
}

How to cite this paper: Gustin, A. (2022). An Agonistic Theory of Democratic Parliamentarism. The Case of the Walloon Parliament. Open Journal of Political Science, 12, 89-107.

https://doi.org/10.4236/ojps.2022.121006

Received: December 6, 2021

Accepted: January 21, 2022

Published: January 24, 2022

Copyright $\odot 2022$ by author(s) and Scientific Research Publishing Inc. This work is licensed under the Creative Commons Attribution International License (CC BY 4.0).

http://creativecommons.org/licenses/by/4.0/

\begin{abstract}
Chantal Mouffe is one of the most discussed political theorists of recent years. One of her most important theoretical contributions is her critique of deliberative democracy for its inability to think the political in terms of antagonism and dissensus. The aim of this paper is therefore to examine to what extent Mouffe's theory of democracy, which she calls "agonistic pluralism" and which she proposes as an alternative to deliberative democracy, can be used to think about the role of the parliamentary institution in a democratic polity. To this end, we mobilize a qualitative method based on the realisation of fifteen semi-structured interviews in order to analyze the case of the Walloon Parliament, with the aim of showing how democratic parliamentarism realizes the staging of the antagonism which, according to Mouffe, founds the domain of the political ${ }^{1}$.
\end{abstract}

\section{Keywords}

Chantal Mouffe, Agonistic Democracy, Democratic Theory, Parliament of Wallonia

\section{Introduction}

Deliberative democracy states that "it is a necessary condition for attaining legitimacy and rationality with regard to collective decision making processes in a polity, that the institutions of this polity are so arranged that what is considered

\footnotetext{
${ }^{1}$ The present article received the prize of the David-Constant Medal (2020). The prize is awarded to a scientific contribution written the year following the graduation of the winner of the David-Constant Medal. The medal rewards the best student graduated in Law, Political Science or Criminology, for his/her undergraduate and postgraduate performance at the Faculty of Law, Political Science and Criminology of the University of Liège.
} 
in the common interest of all results from processes of collective deliberation conducted rationally and fairly among free and equal individuals" (Benhabib, 1996: p. 69). The deliberative model is the most prominent contemporary theory in terms of theorizing the virtues of democracy and its legitimacy (Dryzek, 2007: p. 237; Elstub \& McLaverty, 2014: p. 1). Deliberative democracy theorists argue, among other things, that democratic legitimacy is rooted in the valorisation of deliberation, discussion, debate, consultation, consultation and participation: from this perspective, the centrality of the parliamentary institution in a democratic polity would then be explained by the fact that it constitutes "the emblem of institutional deliberation" (Tavoillot, 2019: p. 188).

Deliberative democracy is however regularly criticized for its inability to think of a democratic regime in political terms. For instance, Ian Shapiro has denounced the fact that deliberative theory minimizes the nature of conflict in politics, which is above all a fracture between divergent interests taking place in a situation of unequal power (Shapiro, 1999). More fundamentally, the political theorist Chantal Mouffe, conceiving the realm of politics as one of exclusionary antagonism, concludes that the theory of deliberative democracy, as it is usually formulated, is incapable of politically thinking a democratic regime, as it does not take into account the antagonistic and hegemonic nature of the political (Mouffe, 1999a; 2016: pp. 19-26).

Although parliamentary studies constitute "an old and well-explored domain" (Benoît \& Rozenberg, 2020: p. 1), and even though the study of parliamentary conflicts is a burgeoning field of research (see for instance Clark \& Williams 2019; Ilie, 2021), no full-fledged agonistic theory of democratic parliamentarism has yet been properly tested against an empirical study of parliamentary relations. For this reason, we thought it would be useful to examine the extent to which the political theory developed by Mouffe herself, a theory that can be described as "agonistic pluralism", could help us to think about the role of the parliamentary institution in a democratic political regime. More precisely, this paper analyzes the case of Walloon interparliamentary relations, which will aim to demonstrate the agonistic nature of democratic parliamentarism.

Mouffe's academic production does not offer us an agonistic account of democratic parliamentarism in its own right. However, insights from her political theory of democratic regimes can be used as a starting point in order to develop an agonistic theory of democratic parliamentarism. According to Mouffe, democratic politics consist in "trying to defuse the potential antagonism that exists in huma relations so as to make human coexistence possible" (Mouffe, 2018: p. 128 ), i.e., to transform political relations of "antagonism" (struggle between enemies) into an "agonistic" confrontation (struggle between adversaries). In this perspective, this paper aims to underline how the parliamentary institution, as a central institution of democratic politics, contributes to this political agonism.

In order to answer the question of whether Mouffe's agonistic theory can be used to think about a theory of democratic parliamentarism, this article is struc- 
tured in two steps. First, we present Mouffe's agonistic political theory, introducing two notions that, according to her, determine the nature of a political regime, namely the notions of antagonism and hegemony. In a second step, we conduct a sociology of Walloon inter-parliamentary relations in order to demonstrate how the parliamentary institution stages conflict in an agonistic manner. We then conclude this study by showing how Mouffe's agonistic theory allows us to consider the parliamentary democratic regime in an original way, while expressing the need not to totally abandon the deliberative ideal by examining how it could be redefined in an agonistic framework.

\section{Methodology}

In order to confront Mouffe's political theory on the role of the parliamentary institution in a democracy, we have chosen to conduct a case study of the Walloon interparliamentary relations. According to Luc Albarello's definition (2011: p. 16), the case study can be defined "as a set of interrelations, situated in time and located in space". The interest of the case study lies in the fact that it allows one to be at the very heart of the articulation of empirical data and the world of theory through the realisation of a detailed analysis of one (or several) cases. The particularity of this research method lies in the fact that it does not clearly distinguish the boundaries separating the phenomenon at the centre of the study from its context, which makes it an interesting tool for subsequent generalisation. The case study therefore appears to be an interesting methodological tool to create links between political theory and empirical analysis.

In order to conduct this case study and to establish links between our observations and Mouffe's agonistic theory, the present contribution carries out a study of the Walloon inter-parliamentary relations. As the agonistic pluralism defended by Mouffe is defined through the staging of conflict, this paper focuses on the study of the Walloon Parliament due to the fact that two particularly conflictual events took place there during the 2014-2019 legislature. On the one hand, the Walloon Parliament played a prominent role in blocking the CETA signing process. This deadlock resulted from a conflict opposing the Walloon government, composed of socialists (Socialist Party, hereafter PS) and centrists (Centre démocrate humaniste, hereafter $\mathrm{CDH}$ ), to the liberals of the Mouvement réformateur (hereafter MR), which remained in the opposition. On the other hand, the Walloon Parliament also took part in the first change of government coalition at the level of the federated entities in Belgium with the motion of constructive distrust addressed to the Magnette government (PS/CDH). This motion led to the replacement of the Magnette government (centre-left) by the Borsus government (MR/CDH, centre-right). The 2014-2019 Walloon Parliamentary term can therefore be regarded as a quite conflictual legislature, which qualifies it for this study of inter-parliamentary relations through the perspective of Mouffe's agonistic pluralism.

Composed of 75 directly elected members, the Walloon Parliament is the leg- 
islative assembly of the Walloon Region, one of the three regional federated entities that make up the complex Belgian institutional structure, together with the different Communities. Established as the Walloon Regional Council by the special law of 8 August 1980, then renamed the Walloon Parliament on 5 April 1995 , the Walloon parliamentary assembly has, by virtue of the federal structure of the Belgian State and the sixth article of this same special law, the competence to legislate in matters such as regional planning, the environment, housing, agriculture, the economy, employment and transport. The Walloon Parliament is therefore a federated parliamentary institution with important prerogatives, and is perfectly in line with the dynamics of the rise in power of the regional authorities (Hooghe, Marks, \& Schakel, 2010), both in terms of autonomy and power of self-rule and in terms of shared rule. Walloon MP is elected for a four-year term. While there is a strong integrated political elites in Belgium, Walloon MP form a parliamentary regional political class (Dodeigne, 2014).

From the point of view of data collection and data analysis, this research mobilises a qualitative method based on the realisation of fifteen semi-structured interviews between September 2019 and February 2020. The number of interviewees was determined according to the principle of saturation. The choice of conducting semi-structured interviews was justified by the need to distinguish the perceptions of certain actors regarding the nature of Walloon parliamentary interactions. The people interviewed were interviewed because of their knowledge of the Walloon parliamentary world, in particular by virtue of a certain seniority within the Walloon Parliament. Twelve of the interviewees were Walloon parliamentarians during the 2014-2019 legislature. Two members of the Walloon Magnette government and a federal MP were also interviewed. These interviews were then exhaustively transcribed and examined through a content analysis, using the tagging technique. Each tag corresponded to a category of analysis and was used to structure the empirical analysis presented in this paper (for example, one of the tags concerned the role of committee chairs. Another was the relationship of parliamentarians with the PTB, etc.). The list of the various people met in the framework of this contribution is available in the appendix.

This section aimed to introduce the methodological aspects underlying this research. We now move to the third section of this paper, which presents the theory of agonistic pluralism advocated by Mouffe. More specifically, the next section is structured in three steps. First, it introduces the notion of antagonism, which, according to Mouffe, founds the realm of the political. Secondly, the notion of hegemony, which can be regarded as one of the distinctive features of Mouffe's political theory with respect to other agonistic theories, is discussed. Thirdly, we make use of those two aforementioned concepts in order to explain how they found Mouffe's democratic theory, which she designates as an "agonistic pluralism".

\section{Mouffe's Theory of Agonistic Democracy}

Agonistic democracy can be defined as "a form of democracy in which conflict 
plays a central role", or as "a radical democratic theory that values conflict as a tool for creating plural political identities, whose continuous oppositions give democratic politics its ever-renewed incompleteness" (Hayat, 2013). For theorists of agonistic democracy, conflict should not be eliminated, but rather managed so that its expression takes place within the framework of democratic institutions that aim to pacify human relations and stage this conflictuality. In this section, we present Mouffe's agonistic political theory, based on the concepts of antagonism and hegemony, before showing how these two notions characterise the democratic phenomenon according to her.

\subsection{The Antagonistic Dimension of the Political: From Carl Schmitt to Chantal Mouffe}

At the heart of Mouffe's political theory is the distinction between "the political" and "politics". The political refers, at the ontological level, to the "antagonistic dimension which is inherent to all human societies" (Mouffe, 2013: p. 2), while politics designate to "the set of practices and institutions through which an order is created, organising human coexistence in the context of conflictuality provided by the political" (Mouffe, 2005: p. 9). This distinction between the two concepts is fundamental in Mouffe's thinking, as she builds her theory of democracy on the impossibility of overcoming the conflictual dimension of the polis - the dimension of the political. Indeed, for Mouffe, the dimension of antagonism present in any human society is unsurpassable and will always be present. It is therefore necessary to start from this observation in order to construct a theory of democracy; otherwise, it cannot be translated into a political system. For example, Mouffe criticises deliberative theory because she considers it incapable of thinking of the political as an antagonism.

In constructing her political theory in her most recent work, Mouffe draws on the writings of Carl Schmitt (1932), while rejecting his theory of the irreconcilability of liberalism and democracy (Mouffe, 1992; 1999b: pp. 38-53), using the German jurist's distinction between friends and enemies to determine the field of politics. In The Notion of the Political, Schmitt defines the specificity of the political as the discrimination between friend and enemy (Schmitt, 1932: p. 64): the political is always about the creation of an us versus a them. According to Schmitt, it is this discrimination between friends and enemies that allows the field of politics to be differentiated from the fields of morality, economics and aesthetics, since it is only in politics that such an opposition is created (Schmitt, 1932: p. 63).

Following this logic, Mouffe uses Schmitt's discriminative approach to construct her theory of democracy. To this end, and in order to determine how the logic opposing friends and enemies is formed, Mouffe uses the notion of "constitutive exterior" developed by Henry Staten and inspired by the work of Jacques Derrida (Staten, 1986). Through this concept, Staten highlights the fact that an identity is always constituted through a differentiation that takes place in a hierarchical manner. The constitution of an identity is then always based on the 
exclusion of something, this showing that all identity is relational, and that "the affirmation of a difference is a precondition for the existence of any identity i.e. the perception of something other which constitutes its exterior" (Mouffe, 2013: p. 5). In order to illustrate this phenomenon, Mouffe cites some examples of such discriminations: the form that defines itself in opposition to matter, black versus white, or man versus woman. As for the realm of politics, this distinction takes the form of Schmitt's opposition between friends and enemies: it is a matter of forming a political community by determining another than itself that "constitutes its exterior" (Mouffe, 2005: p. 15).

\subsection{Politics and Hegemony}

The concept of politics thus refers to an antagonism between friends and enemies, i.e. an us defining itself vis-à-vis a them. However, according to Mouffe, a second concept is necessary in order to define a democratic politics, namely that of hegemony. The notion of hegemony refers to the fact that society is "the product of a series of practices whose aim is to establish order in a context of contingency" (Mouffe, 2013: p. 2), which order can be political, economic, or deliberative. The concepts of hegemony, or even of counter-hegemony, thus postulate that in the impossibility of determining a rational basis for a social order, any socio-political configuration results from articulatory discursive practices through which the meaning of institutions and social relations are fixed in a temporary and precarious manner. In this perspective, discourse, which includes both linguistic and non-linguistic elements (Laclau \& Mouffe, 2001: p. 93), then defined as "a social and political construction that establishes a system of relations between different objects and practices" (Howarth \& Stavrakakis, 2000: p. 3), plays a fundamental role in the formation of political identities.

The notion of hegemony thus emphasizes the role of representation, conceptualised in terms of discursive articulations, in revealing the constructed character of social reality and political subjectivities. However, as Yannis Stavrakakis (2017: p. 675) points out, this constructivism is a constructivism "that knows its limits", since the fixation of social meaning always remains precarious, and this for two reasons. On the one hand, it is always the representation of an incommensurable totality, hence the invocation, in the populist logic, of an "empty signifier" (Laclau, 2005a: pp. 69-71) aiming to create the unity of the group through a phenomenon that is not conceptual but nominal. From the perspective of a logic of equivalence (as opposed to a logic of difference, which emphasises the singularity of social demands, making the constitution of an antagonistic pole impossible), the homogenising function of the name is ultimately fulfilled by a pure name: that of the leader (Laclau, 2005b: p. 40).

On the other hand, the second element threatening a hegemonic order is the open character of the social, which brings us back to the concept of antagonism previously discussed. Indeed, we have seen that in Mouffe's theory any political identity is constituted by designating an us versus a them, that is, through 
Schmitt's discrimination between friends and enemies. This discrimination, produced through discourses, which Laclau calls "popular discourses of equivalence" (Laclau, 2005b: p. 38), and which aim to establish a boundary dividing the social into two camps, is at the root of the process of hegemony, since a re-articulation of a system of meaning is rooted in the inability of a political system to satisfy social demands, which are then articulated as claims. This division of the social as a result of an inability to socially isolate these demands through a logic of difference can, however, intervene from any position in a social system: "any position in a system of differences, insofar as it is negated, can become the locus of an antagonism" (Laclau \& Mouffe, 2001: p. 117). Consequently, there is a plurality of possible antagonisms in the social, and as many potential hegemonic configurations. Dislocation and antagonism are thus two phenomena that threaten discursive representations, but at the same time stimulate practices aimed at re-articulating the meaning of relations between political objects and subjects.

\subsection{Beyond Deliberative Theory: An Agonistic Pluralism}

Mouffe finds deliberative democracy incapable of thinking about the political in its antagonistic and hegemonic dimensions, and opposes it to a democratic theory that she describes as "agonistic pluralism". For the political theorist, the democratic phenomenon is based on an ineradicable tension between two very distinct political traditions: that of political liberalism and that of democratic thought. According to her, liberal democracy is based on a tension between these two logics that cannot be reconciled, and one can always prevail over the other, a fact that Mouffe describes as a "democratic paradox" (Mouffe, 2009). The agonistic pluralism proposed by the theorist is then defined by an "agonistic confrontation between conflicting interpretations of liberal-democratic values" (Mouffe, 2009: p. 9), in the sense that the very content of these values remains constantly discussed, debated, and questioned, and that the stabilisation of the conflict between them can only be achieved through contingent hegemonic practices.

The solution proposed by Mouffe is therefore to some extent pluralist, in the sense that several interpretations of liberal and democratic values are in conflict. However, what is meant by agonistic confrontation? Indeed, so far, we have always treated the distinction between an us and a them as a confrontation between friends and enemies, which takes place when the other is perceived as threatening us and denying our identity. However, a relationship between an us and a them can also take other forms than an antagonistic opposition: this is where the democratic phenomenon comes in, in that it aims to transform this antagonism into what Mouffe calls an agonistic relationship. In other words, as we have seen, the domain of politics refers to the potential antagonism inherent in the management of the city: it is this antagonism that democracy will aim to break down. 
This will require, according to Mouffe, to establish a bond between opponents, so that they do not perceive each other as enemies to be eradicated, "seeing their demands as illegitimate, which is precisely what happens with the antagonistic friend/enemy relation" (Mouffe, 2005: p. 20). According to the theorist, this relationship needs to be transformed into an agonistic one, "where the conflicting parties, although acknowledging that there is no rational solution to their conflict, nevertheless recognise the legitimacy of their opponents" (Mouffe, 2005: p. 20). In this agonistic opposition, opponents then confront each other through a hegemonic struggle that aims to redefine the "hegemonic politicoeconomic articulations which determine the specific configuration of a society at a given moment" (Mouffe, 2005: p. 33); opponents no longer identifying themselves as enemies, but as opponents belonging to the same political association and sharing a common political space within which the conflict takes place.

This means, therefore, that conflict should not be eradicated, or mitigated by democracy, but that democracy should sublimate it and ensure that it can be expressed in a non-antagonistic, non-violent, and democratic way, since a return to an antagonistic relationship will always remain a possibility: "politics is an economy of violence, in both senses of the word-a way of organising, distributing, managing violence, but also a way of reducing it, deferring it, moderating it' (Delruelle, 2020: p. 181). In Mouffe's agonistic pluralism, democratic activity is therefore embodied by a confrontation between hegemonic and counter-hegemonic projects aimed at reinterpreting liberal and democratic values.

In conclusion, in this perspective of agonistic pluralism, the parliamentary institution plays a fundamental role in a political regime, since parliament is the place where antagonism is transformed into agonism par excellence: it is indeed through the gathering and participation of different political forces in the same political institution that the enemy becomes the adversary, and that a certain legitimacy is thus attributed to it. This theoretical proposition identified in Mouffe's agonistic theory, namely that of a parliament contributing to the transformation of antagonism into agonism, is therefore the hypothesis that we will seek to confirm in our analysis of the cases of parliamentary relations. To do so, we will analyze the data collected during our interviews concerning the nature of Walloon parliamentary relations through Chantal Mouffe's agonistic model of political relations.

\section{The Parliament of Wallonia and the Antagonistic Nature of Political Relations in Democracy}

In Mouffe's agonistic theory, the parliamentary hemicycle is an institution aimed at transforming antagonism, a political relation in which each political camp perceives itself as a reciprocal enemy, into an agonistic relationship, which pits adversaries against each other. In order to provide the best interpretation of this metamorphosis of political relations within a parliamentary political regime, Mouffe often finds it useful to refer to the explanation of Élias Canetti, an author 
she regularly quotes through this extract from his book Masse et Puissance:

A parliamentary vote does nothing but ascertains the relative strength of two groups at a given time and place. Knowing them beforehand is not enough. One party may have 360 members and the other only 240 , but the actual vote is decisive, as the moment in which the one is really measured against the other. It is all that is left of the original lethal clash and it is played out in many forms, with threats abuse and physical provocation which may lead to blows or missiles. But the counting of the vote ends the battle (Canetti, 1960: p. 220).

Parliament, considered here as an institution, is "the highest level place where the whole range of representative political convictions can be expressed" (Interview 16). Thus, in Mouffe's agonistic perspective, parliament is not only "the emblem of institutional deliberation", but also the symbol of the pluralist agonism she seeks to defend, in that it tends to establish a "kind of common bond" (Mouffe, 2005: p. 20) between political opponents with the aim that they do not identify themselves as enemies, but as opponents to whom they recognise some legitimacy. This common bond, as will be argued in this section, is established through the participation of different political forces in the same institution in which a logic of elite socialisation prevails.

\subsection{An Agonistic Interpretation of Formal and Informal Contacts between Walloon MPs}

The parliamentary hemicycle is often perceived as an arena of intense verbal jousting, where oratorical struggles multiply, and where two camps, those of the majority and the opposition, confront each other without respite, and without concession. However, this image of a parliament as a theatre of confrontation between political forces remains largely incomplete, because it omits an important fact: being a parliamentarian means working, collaborating, or at least being in contact with one's peers throughout one's term of office, or even during several legislatures. Parliament is therefore a place of lively social interaction for MPs:

Parliament is a lot of interpersonal relations, and when you live five years with people, in easy moments, as well as in more difficult moments, tense moments, as well as in moments of relaxation, you learn to appreciate people, there are affinities that are created. (...) At some point, there is a human factor at work, and it is important to build working relationships and trust. We are there to defend ideas, to have a certain vision of society, but we don't do that alone. That's what democracy is all about. It means working with each other, first of all with citizens, with associations, with companies, (...), but it also means being able to talk to political opponents, they are not always enemies (Interview 1).

For an MP, exchanging with his or her parliamentary counterparts is a regular 
necessity if one wants to see a project succeed: it is indeed a matter of dialogue, arguing, convincing, persuading, and even negotiating support for a proposed amendment or legislation. Like any professional activity, the parliamentary mandate requires contact with people who often have their own personalities and backgrounds, and who defend ideas and values that are different from our own. However, this does not prevent Walloon MPs from making friends over the course of their mandates, years and working meetings. Thus, the Walloon MPs interviewed for this research all claim to have established strong ties with other MPs:

The Walloon parliamentary world knows each other well. Although there are changes in each legislature, I would say that we have known each other for about twenty years. These are people with whom we have had battles, I would say by image, at close quarters, sometimes with a sword, and we know each other anyway, and things generally go relatively well (Interview 9).

The organisation of parliamentary work through the establishment of committees proves to be a relevant factor in explaining how the parliamentary institution is capable of binding the political elite of a democratic regime in agonistic relationships. Indeed, if such an organisation of parliamentary work responds above all to a logic of division of labour, with MPs specialising in specific subjects, thereby improving the quality of parliamentary activity in its legislative and control dimensions, the distribution of MPs in such working groups is also an opportunity for them to establish contact with some of their counterparts working on the same themes, or even with the minister whose competences correspond to their areas of specialisation:

It is true that a whole series of other contacts take place in an informal way (...). Now, if you have work in committee that sometimes goes on a bit late, which is quite frequent, then solutions have to be found (...). And that's where the real contacts are made. And friendships, moreover (Interview 6).

The parliamentary institution thus plays a fundamental role in transforming antagonism into a relationship between adversaries, with all the political forces of a democratic regime being brought together and entering into relations. This transformation of enmity into an agonistic relationship does not only take place through the formal relationships within the institution, but also through a series of informal contacts. The parliamentary cafeteria, for example, has a special place in the Walloon parliamentary world. It is difficult to see the difference between what is a professional relationship and what is a purely cordial one. However, this ambiguity seems to characterise the relationships that can develop in the parliamentary world:

The informal links that can be established in the cafeteria, during a field 
mission, etc. can be precious for the future, for example to be able to make a phone call to clear up certain things. The all too rare space where you can co-construct something with others is precious, really precious. And it is a space that is created in the interstices, it is exceptional that there can really be lines that move during the parliamentary debates themselves, it is not in committee, even less in plenary that opinions change, it is rare. There really has to be major external pressure for this to happen. (...) And this work is done in informal meetings, working groups, etc. (Interview 4).

Several parliamentary functions are useful to understand how the parliamentary institution allows the transformation of an antagonism into a relationship of an agonistic nature. For instance, the parliamentary group leader occupies in many ways a central place in the conflict pacification mechanism of a parliamentary regime. Fulfilling a multifaceted role, he or she is in fact "the transmission belt between the government and the majority links, which implies an immeasurable number of meetings in the shadows to try to negotiate the content of texts, to amend them, upstream of the parliamentary work" (Interview 9). In the same vein, the President of the Parliament is the assembly's policeman: "he gives and takes away the floor, he can even go so far as to expel people from the Chamber" (Interview 14). He is in fact responsible for the smooth running of the proceedings, which he does by maintaining order, giving the floor, and generally having the "useful and necessary" powers (Rules of Procedure of the Walloon Parliament, Article 17) for this purpose. In this perspective, the President of the Parliament must then be "the most correct ally of the opposition" (Interview 17), as it is his role to ensure that the latter's rights are respected. Finally, even if his or her functions are in some respects incomparable, the committee chairperson occupies a similar position in committee work to that assumed by the President of Parliament in plenary session. The committee chairperson remains the first point of contact for the opposition during the work and debates, and must ensure that the opposition's voice is heard:

Having been a committee chair, my job was to work (...) to create the best possible atmosphere, a lot of serenity in the debates, to have a fair position as chair because when you are a committee chair, you may have a political colour, but you must necessarily be there for everyone (Interview 10).

The functions performed in the framework of certain mandates, such as those of the President of the Parliament and of the Committee Chair, are therefore crucial in transforming an antagonistic relationship into an agonistic one, where political opponents attribute mutual legitimacy to each other and define themselves as adversaries, because it is their task to ensure that the opposition has a voice. In this respect, it is also the complex task of the presidents to find a balance between the rights of this opposition and those of the majority, since if this balance is not found, the possibility of the resurgence of a relationship of enmity cannot be definitively eliminated. 


\subsection{Filibustering Practices and the Attitudes of Walloon MPs towards Belgian Labour Party's Deputies as Reminders of the Conflictual Nature of the Political}

It is from this perspective that parliamentary filibustering practices can be interpreted. Beyond its folkloric and strategic aspects, the parliamentary filibuster constitutes a formidable reminder of the fundamentally antagonistic nature of political relations. In their excellent study of this phenomenon, Mathias El Berhoumi and John Pitseys point out that these practices, through the conceptual metaphor of filibustering, allows parliamentary discussion to be associated with the register of war (El Berhoumi \& Pitseys, 2016). Quoting the work of JeanJacques Urvoas and Magali Alexandre, they refer to filibustering as a conflictual practice "based on the idea that parliamentary life is, like a battlefield, the theatre of manoeuvres of a continuous conflict between parties and political groups" (Urvoas \& Alexandre, 2012: p. 14). Parliamentary filibustering, apart from its purely procedural and deliberative justifications, effectively allows the opposition to assert its rights in cases where it would feel aggrieved. In other words, in Mouffe's agonistic perspective, filibustering constitutes both a particular register of the staging of parliamentary political conflictuality, but also a kind of last warning that the opposition addresses to the majority, i.e. a final reminder of the fundamentally conflictual nature of politics and of the eternal possible return to antagonism that characterises it.

Another manifestation of the ineradicable nature of conflict in politics can be found in the attitude of the Walloon parliamentarians towards the deputies of the Belgian Labour Party (PTB). Thus, if it is true that the representatives of the four mainstream parties ( $\mathrm{cdH}$, ECOLO, Mouvement réformateur, Parti socialiste), through recurrent participation in parliamentary affairs, know each other and are particularly familiar with the practices of the parliamentary chamber, their attitudes towards the Walloon MPs of the PTB are not entirely devoid of antagonism, since an element of hostility is indeed to be found in the attitude of the Walloon elected representatives towards them, as can be seen from this extract from an interview with a Walloon MP:

In the Parliament, all political opinions taken together, yes, I have been able to have really interesting contacts with democratic political parties. Do I have to say it, I am not very friendly with those who are extreme. I'm not at all, and so sometimes, in the Parliament, I have a little bit more trouble with the ten PTB parliamentarians, because Marxist ideas are not a reflection of society. (...). I don't really want to go towards people whose leitmotiv is very populist (...), and so it bothers me a bit more, I always have a bit more trouble (Interview 8).

Of course, this state of affairs is probably not only due to the attitude of the parliamentarians of the mainstream parties towards the elected members of the PTB, but also to a process of self-exclusion on the part of the latter in order to distinguish themselves. In the end, this incompatibility between the PTB and its 
rivals suggests that the process of creating political identities takes place through a dialectic between an us and a them, as well as through a certain relationship to a constitutive exterior, since if PTB MPs, on the one hand, and representatives of other democratic parties, on the other hand, tend to avoid each other, it is because they cannot escape this collective identity dichotomy that serves to define who they are.

And it is in such cases, where antagonism has not yet been completely eliminated, that the parliamentary institution proves to play a role incomparable to that played by other democratic institutions. Indeed, the parliamentary system forces the most antagonistic political forces to frequent the same institution, the desire to influence decision-making as much as possible forcing political parties to link up with other political forces that are considered hostile. Parliamentary democracy thus offers a "common symbolic space within which the conflict takes place" (Mouffe, 2016: p. 34), as this extract from an interview with a PTB MP indicates, who explains that although a certain distance is required with other parties, contacts with them are nevertheless necessary:

We find it important to have contacts with the other parties, because contrary to what our enemies say, (...) at some point, we will have to make compromises with the other parties to obtain small victories. (...) In this sense, in relation to our objectives, yes, you must have contacts. But having contacts doesn't mean that we go to eat with them, that we drink our coffee with them. There's a refectory there, we don't go regularly to the refectory to meet them. So I wouldn't go so far as to say that we have to protect ourselves from them, because they don't scare us [laughing], but yes, there is a distance to be kept, and a contact to be kept in both directions (Interview 13).

The parliamentary regime actually forces political opponents to recognise each other, to a certain extent, as mutually legitimate, because of the legitimacy induced by the elective appointment procedure, but also through their common participation in the same institution, the inclusion of different political forces within the same institutional framework bringing them together. Of course, as the case of the PTB shows, this does not mean that the parliamentary institution is devoid of a dimension of exclusion, which is characteristic of politics: in this respect, while it is undeniable that the parliamentary regime does indeed include a deliberative dimension, a dimension that undoubtedly plays a role in the transformation of antagonism into agonism, agonistic democracy seems much more appropriate than deliberative theory when it comes to explaining certain exclusionary phenomena, such as the conflictual relationship between the elected members of the PTB and those of other French-speaking political parties.

\subsection{Deliberative Theory: A Critic}

These phenomena of exclusion are not only related to factors of human relations, but also to the very nature of a deliberative political regime. Consider the 
following example. One of the criteria defining the quality of a deliberation is that of equality, a notion itself intrinsically linked to that of inclusion (Beauvais, 2018): a decision would be democratic if those affected by it are able to influence it (Goodin, 2007). However, even if a deliberative body, in this case the parliamentary institution, is sufficiently inclusive with regard to this criterion of equality, this does not mean that all participants have the same capacity to participate. Speaking in a debate is a learning process, and not everyone starts out on an equal footing: for example, a lawyer will often find it easier to argue the case than a worker (Hooghes, 1999). In parliament, this is often reflected in the learning of a series of rules, sometimes written, sometimes customary, in terms of parliamentary procedures, but also in a way of expressing oneself, as a Walloon PTB MP pointed out:

There is really a challenge in terms of semantics, in terms of vocabulary. The first challenge is to understand. Because it's clear that all this abstruse vocabulary, where you can say everything and nothing in one sentence, where you can say the opposite one day, the opposite the other day, all this vague language obviously serves an objective which is the opposite of pedagogy, which is really that people don't follow, that people don't understand what they are talking about. There is indeed a whole learning process at that level, and it is clear that it is an obstacle to participating in democratic life for people who are not academics, for people who do not necessarily have the capacity or the necessary training. In fact, the Walloon Parliament is not at all the expression of society. No, if there were as many lawyers in society as in the Walloon Parliament, there would be law firms everywhere. I mean, no, in the Walloon Parliament, it is lawyers, university professors, etc. And that shows in little details. And you can see this in small details, you can see it in the vocabulary (...) (Interview 12).

Beyond a criticism of Walloon representation, this interview extract highlights the fact that expressing oneself in the parliamentary chamber is neither innate nor given to everyone, and requires the ability to master the hegemonic parliamentary language. Walloon parliamentary exchanges constitute a particular rhetoric, or, to use the terms employed by Iris M. Young (2000), a deliberative order, where certain procedural or linguistic norms form and determine a set of rules from which it is not always easy to distinguish the prescriptions. Thus, during the interviews, many MPs mentioned the need to train newcomers to the parliamentary process, with the various political parties, like the Walloon Parliament, organising training sessions at the beginning of their term of office to remedy certain shortcomings. For a party whose members are mostly entering a chamber for the first time, such as the PTB, this apprenticeship is made even more difficult by the lack of accumulated knowledge and experience of the functioning of a parliament, which we could describe as a "parliamentary capital deficit" that reinforces the exclusive dimension of the parliamentary system, something that the deliberative theory of democracy is unable to grasp correctly. 


\subsection{Paving the Way for a Hegemonic Analysis of Democratic Parliamentarism}

In the end, we wanted, through this case study of Walloon parliamentary interactions, to highlight two elements, which we will now summarise. On the one hand, we have pursued the objective of confirming that the nature of political relations in a democracy is indeed agonistic, i.e. relations between adversaries, where opponents do not perceive themselves as enemies, but as adversaries who attribute mutual legitimacy to each other through participation in one and the same institution bringing together all the political forces of a political community. On the other hand, we have also highlighted the particular role of the parliamentary regime in transforming an antagonistic relationship into an agonistic one. The many parliamentary mechanisms that have been put in place to sustain this type of relationship show how the parliamentary system strikes an unstable balance between enmity and agonism, since notwithstanding the essentially agonistic nature of parliamentary interactions, the practices of parliamentary filibustering and, to a certain extent, the attitude of MPs towards PTB representatives symbolise the ineradicable conflictual and fundamentally antagonistic dimension of the realm of politics.

Another theoretical potential of Mouffe's agonistic democracy that has not been highlighted in this contribution lies in the understanding of the hegemonic dimension of parliamentary activity. Indeed, while we have highlighted the role of the parliamentary institution in transforming and maintaining antagonism into agonism, another key concept in the political theorist's thinking, namely that of hegemony, has not been addressed in this study. In this perspective, it would be a question of examining to what extent parliamentarianism, as a state institution, could be considered, as Nicos Poulantzas (2013) argued, as the material condensation of a relation of forces between classes and class fractions. According to Mouffe, the state is indeed itself hegemonically structured, and constitutes a "major space for counter-hegemonic struggle" (Mouffe, 2018: p. 100). In the theoretical perspective outlined by Mouffe, the parliamentary institution thus occupies a nodal function in the development of this hegemonic confrontation.

The Walloon Parliament has recently played a leading role in the counter-hegemonic opposition to the Comprehensive Economic and Trade Agreement (CETA), which has been negotiated since 2009 by the Canadian and European authorities, and whose opposition by Walloon parliamentarians to the process of delegating powers to the federal government in the course of 2016 helped to make it a major political issue. The Walloon parliamentary opposition to the CETA, which marked an important turning point in the increase of regional influence on European policies (Tatham, 2018), can be explained in particular by Belgian multilevel party politics (Bursens \& De Bièvre, 2021), by the important and pluralist mobilisation of civil society in its regard (Gheyle, 2020), as well as by the strengthened links between these civil society actors and the Walloon parliamentary world. The CETA episode thus testifies to the potential 
of the parliamentary institution in the context of a counter-hegemonic struggle, since by spearheading opposition to the treaty, the Walloon Parliament helped to demonstrate that a subversive politics of contemporary neoliberal hegemony was possible, while at the same time seeming to confirm the Mouffian hegemonic hypothesis concerning the parliamentary institution, which future research could seek to demonstrate.

\section{Conclusion}

In the agonistic pluralism proposed by Mouffe, parliament is entrusted with the role of transforming the antagonism that can take place between political opponents into a relationship of an agonistic nature, which sees opponents mutually recognizing the legitimacy of their claims, rather than enemies seeking to eradicate each other. In this respect, the sociological study of Walloon parliamentary interactions has enabled us to observe that, on the one hand, the nature of Walloon parliamentary relations is indeed that of a relationship between adversaries, characteristic of the democratic pluralism advocated by Mouffe, and that, on the other hand, the Walloon parliamentary institution occupies a fundamental place in the maintenance and perpetuation of this agonism.

The agonistic pluralism proposed by Mouffe thus seems to offer, in a general way, an original perspective on the democratic phenomenon, as well as on the place of the parliamentary institution in a democratic political regime, since by not denying the constant possibility of a return to a certain antagonism, the emphasis put by the political theorist on the character of the relations linking political opponents within the parliamentary hemicycle allows us to better define the nature of political relations in democracy. Far from being monolithic, inter-parliamentary relations turn out to be more complex than they appear. Indeed, on the one hand, democratic parliamentarism allows for the sublimation of potential conflicts, by offering political representatives a space in which these confrontations and oppositions can be expressed. On the other hand, the functioning of the parliamentary institution also sees the blossoming of links of cooperation, mutual aid, and even trust and friendship between political representatives, thus contributing to the perpetuation of the democratic system and the cohesion of the political community.

Finally, Mouffe's agonistic theoretical proposal is, let us not forget, set in a context where deliberative democracy is the predominant democratic theory in the field, and is also a political ideal to be achieved by many activists or political representatives. The deliberative theory of democracy, however, seems to be unable to grasp the fundamentally political dimension of a democratic regime. However, rather than condemning a theory that has been the subject of theoretical debate for the past thirty years, it would be useful to see how this theory could be reconciled with the agonistic pluralism advocated by Mouffe, in the sense that the latter seems to be better able to think of the political in its agonistic and hegemonic dimensions. An analysis of the hegemonic dimension of 
democratic parliamentarism could therefore be coupled with a careful study of the link between prevailing hegemony and political deliberation. In other words, it would make sense to see how deliberative theory could be deployed in agonistic and hegemonic terms, for instance by mobilising Mouffe's democratic theory to deal with the analysis of some empirical cases, which would also contribute to the rapprochement between political theory and political science.

\section{Conflicts of Interest}

The author declares no conflicts of interest regarding the publication of this paper.

\section{References}

Albarello, L. (2011). Choisir l'étude de cas comme méthode de recherché. De Boeck.

Beauvais, E. (2018). Deliberation and Equality. In A. Bächtiger, J. S. Dryzek, J. Mansbridge, \& M. E. Warren (Eds.), The Oxford Handbook of Deliberative Democracy (pp. 144-153). Oxford University Press. https://doi.org/10.1093/oxfordhb/9780198747369.013.32

Benhabib, S. (1996). Toward a Deliberative Model of Democratic Legitimacy. In S. Benhabib (Ed.), Democracy and Difference. Contesting the Political (pp. 67-94). Princeton University Press. https://doi.org/10.1515/9780691234168-005

Benoît, C., \& Rozenberg, O. (2020). Introduction to the Handbook of Parliamentary Studies. In C. Benoît, \& O. Rozenberg (Eds.), Handbook of Parliamentary Studies: Interdisciplinary Approaches to Legislature. Edward Elgar.

https://doi.org/10.4337/9781789906516

Bursens, P., \& De Bièvre, D. (2021). Seizing the Moment: Regional Opportunity Structures and Wallonia's Temporary Veto of the EU-Canada Bilateral Trade Agreement. Regional \& Federal Studies. https://doi.org/10.1080/13597566.2021.2007477

Canetti, E. (1960). Crowds and Power. Penguin.

Clark, J. H., \& Williams, R. L. (2019). Leadership Power, Preference Homogeneity, and Legislative Party Conflict. The Journal of Legislative Studies, 25, 489-510. https://doi.org/10.1080/13572334.2019.1698112

Delruelle, E. (2020). Philosophie de l'État social. Civilité et dissensus au XXI' siècle. Kimé.

Dodeigne, J. (2014). (Re-)Assessing Career Patterns in Multi-Level Systems: Insights from Wallonia in Belgium. Regional \& Federal Studies, 24, 151-171. https://doi.org/10.1080/13597566.2013.865605

Dryzek, J. S. (2007). Theory, Evidence and the Task of Deliberation. In S. W. Rosenberg (Eds.), Deliberation, Participation and Democracy: Can the People Govern? (pp. 237-250). Palgrave Macmillan. https://doi.org/10.1057/9780230591080 11

El Berhoumi, M., \& Pitseys, J. (2016). L'obstruction parlementaire en Belgique. Courrier Hebdomadaire du CRISP, 4, 5-78.

Elstub, S., \& McLaverty, P. (2014). Introduction: Issues and Cases in Deliberative Democracy. In S. Elstub, \& P. McLaverty (Eds.), Deliberative Democracy: Issues and Cases (pp. 1-16). Edinburgh University Press.

Gheyle, N. (2020). Huddle up! Exploring Domestic Coalition Formation Dynamics in the Differentiated Politicization of TTIP. Politics and Governance, 8, 301-311.

https://doi.org/10.17645/pag.v8i1.2588

Goodin, R. E. (2007). Enfranchising All Affected Interests, and Its Alternatives. Philoso- 
phy and Public Affairs, 35, 40-68. https://doi.org/10.1111/j.1088-4963.2007.00098.x

Hayat, S. (2013). Démocratie agonistique. GIS Démocratie et Participation.

Hooghe, L., Marks, G., \& Schakel, A. H. (2010). The Rise of Regional Authority: A Comparative Study of 42 Democracies. Routledge. https://doi.org/10.4324/9780203852170

Hooghes, M. (1999). The Rebuke of Thersites. Deliberative Democracy under Conditions of Inequality. Acta Politica, 34, 287-301.

Howarth, D., \& Stavrakakis, Y. (2000). Introducing Discourse Theory and Political Analysis. In D. Howarth, A. J. Norval, \& Y. Stavrakakis (Eds.), Discourse Theory and Political Analysis: Identities, Hegemonies, and Social Change (pp. 1-23). Manchester University Press.

Ilie, C. (2021). Discussion, Dispute or Controversy? Paradigms of Conflict-Driven Parliamentary Practices. Journal of Language Aggression and Conflict, 9, 237-270. https://doi.org/10.1075/jlac.00047.ili

Laclau, E. \& Mouffe, C. (2001). Hegemony and Socialist Strategy: Towards a Radical Democratic Politics. Verso.

Laclau, E. (2005a). On Populist Reason. Verso Books.

Laclau, E. (2005b). Populism: What's in a Name? In F. Panizza (Eds.), Populism and the Mirror of Democracy (pp. 32-49). Verso Books.

Mouffe, C. (1992). Penser la démocratie moderne avec, et contre, Carl Schmitt. Revue Française de Science Politique, 42, 83-96. https://doi.org/10.3406/rfsp.1992.404277

Mouffe, C. (1999a). Deliberative Democracy or Agonistic Pluralism? Social Research, 66, 745-758.

Mouffe, C. (1999b). Carl Schmitt and the Paradox of Liberal Democracy. In C. Mouffe (Ed.), The Challenge of Carl Schmitt (pp. 38-53). Verso.

Mouffe, C. (2005). The Return of The Political. Verso Books.

Mouffe, C. (2005). On the Political. Routledge.

Mouffe, C. (2009). The Democratic Paradox. Verso Books.

Mouffe, C. (2013). Agonistics. Thinking the World Politically. Verso Books.

Mouffe, C. (2018). Pour un populisme de gauche. Albin Michel.

Poulantzas, N. (2013). L'Etat, le pouvoir, le socialisme. Les Prairies Ordinaires.

Schmitt, C. (1932). La notion de politique. Flammarion.

Shapiro, I. (1999). Enough of Deliberation: Politics is about Interests and Power. In S. Macedo (Eds.), Deliberative Politics: Essays on Democracy and Disagreement (pp. 28-38). Oxford University Press.

Staten, H. (1986). Wittgenstein and Derrida. University of Nebraska Press.

Stavrakakis, Y. (2017). Populism and Hegemony. In C. R. Kaltwasser, P. Taggart, P. Ochoa Espejo, \& P. Ostiguy (Eds.), The Oxford Handbook of Populism (pp. 673-695). Oxford University Press. https://doi.org/10.1093/oxfordhb/9780198803560.013.26

Tatham, M. (2018). The Rise of Regional Influence in the EU-From Soft Policy Lobbying to Hard Vetoing. Journal of Common Market Studies, 56, 672-686. https://doi.org/10.1111/jcms.12714

Tavoillot, P. H. (2019). Comment gouverner un peuple-roi? Traité nouveau d'art politique. Odile Jacob.

Urvoas, J. J., \& Alexandre, M. (2012). Manuel de survie à l'Assemblée nationale. L'art de la guérilla parlementaire. Odile Jacob.

Young, I. M. (2000). Inclusion and Democracy. Oxford University Press. 


\section{Appendix-List of Interviewed}

\begin{tabular}{ll}
\hline List of interviewed & References in the text \\
\hline Walloon MP (CDH) & Interview no. 1 \\
Walloon MP (CDH) & Interview no. 2 \\
Walloon MP (CDH) & Interview no. 3 \\
Walloon MP (ECOLO) & Interview no. 4 \\
Walloon MP (ECOLO) & Interview no. 5 \\
Walloon MP (MR) & Interview no. 6 \\
Walloon MP (MR) & Interview no. 7 \\
Walloon MP MR) & Interview no. 8 \\
Walloon MP (PS) & Interview no. 9 \\
Walloon MP (PS) & Interview no. 10 \\
Walloon MP (PS) & Interview no. 11 \\
Walloon MP (PTB) & Interview no. 12 \\
Federal MP (PTB) & Interview no. 13 \\
Member of the Magnette's government & Interview no. 14 \\
Member of the Magnette's government & Interview no. 15 \\
Walloon parliament civil servant & Interview no. 16 \\
\hline
\end{tabular}

